\title{
The measurement of sport sevice quality for unicipalities as local goverment units (Konya case)
}

\author{
Yusuf BARSBUGA, Hayri DEMIR \\ Faculty of Sport Sciences, Selcuk University, Konya, Turkey. \\ Address Correspondence to Y. Barsboğa, e-mail: yusufbarsbuga@hotmail.com \\ This study was summarized from Y. Barsbuga's Master Degree Thesis.
}

\begin{abstract}
The aim of this study was to determine sport activity services municipalities carry out as local management units, consider viewpoints of people benefiting from these services and evaluate them as well. The participants of the study consist of 300 persons in total, including 90 persons from the center of fine arts included in the Meram District Municipality of Konya, 94 persons utilizing the Ertuğrul Gazi Recreational Facility in the Meram District Municipality of Konya and 115 persons from the center of vocational course in the Karatay District Municipality of Konya. In our study, the Service Quality Assessment Scale developed by Lam, Turkish reliability and acceptability done by Gürbüz, was performed. The One-Sample Kolmogorov-Smirnov test examined whether the data showed normal distribution, and it was made clear that the data displayed normal distribution. Since the data appeared to be normally-distributed, the Independent-Sample $\mathrm{T}$ test and the ANOVA test were also used for determining differences between the independent variables. As a result of our study; it was observed that there was no difference when the satisfaction levels of members were considered in the travel time, the marital status and the education level within the sub-dimensions of staff, program, facility and changing rooms in consequence of comparing the service quality expected and perceived from the members participating in the research. But the satisfaction level decreased when the membership duration, the usage frequency and the income level increased. Also, it was determined that the satisfaction levels of participants who had individual membership type and were over the age of 18, were higher than ones having family membership type and aged under 18. As a result of our study; it was observed that the expected and perceived service quality satisfaction approaches of participant members, effected from membership type, membership period, frequence of facility usage and ages of members.
\end{abstract}

Keywords: Municipalities, local governments, sport service quality.

\section{INTRODUCTION}

Human beings have established various administrative systems and organizations, and managed these as well since the first periods of history, though they do not have any characteristics of a modern state. Today public management is a system which relates to the non-stop operation of a state and society order, the production and presentation of goods and services aimed at meeting the collective needs of a public (11).

According to Öztürk (19), the most developed organization of public management is a state. Each state's objective is to strengthen the economical welfare of its own society. The state fulfills the common needs of a society living in national borders; regards, protects and represents their general interests. The state tries to carry out these duties via central and local management institutions (20).
It is not possible to manage all of the public services from the capital cities of the countries. Even if possible, the efficiency and effectiveness of the services become less. Problems and needs such as different conditions of regions, distances to centers, public inclusion in management and better service presentation to public have set the local administrations on stage. For the purpose of fulfilling the common needs of a local community living in a certain geographical field, with the decisive bodies chosen by the public, having duties and authorities given by law, with a specific income, budget and staff, public corporate entities are called local administrations or local managements (9).

Nowadays there are three types of local management units in our country in accordance with the Constitution. These are provincial special administrations, municipalities and villages. Each one of these three local management units was 
arranged by the different laws. Among the local management units, the busiest one is municipality managements in terms of works. Like in many states, in our country municipalities are known as the closest institutions to public. The reason is for that the municipalities' own duties affect the daily life of a public in a direct way (18). Services given by the municipalities to the citizens vary from a country to another country. Furthermore, by increasing and differing public services due to environmental and technological changes and developments, the service number per a municipality has been increasing day by day (15).

The relevant local management units have carried out activities in many fields, sport has been an activity field among these. Like in many fields by the local management units, hereby, the service variety and activities of the municipalities are more in sport services rather than other units. The increasing importance of sport in society, the educational, social and cultural roles of sport and the dignity of international competitions have drawn the public authorities' attention. Sport has been considered to have positive effects on society, which has triggered sport to be regarded as a public service aimed at public benefit (13). Quality in sport services can be defined as 'a capability for fulfilling or going beyond customers' demands from sport' (6).

Service production in sport facilities is virtually based on sport programs to satisfy people. Sport programs involve a process of planning to meet people's attendance demands for sport activities different from each other. Because the availability of a sport organization results from people's needs, and these needs are fulfilled with the sport programs. Sport programs include the basis for sport service production (10).

Sport facilities are required for providing customer satisfaction as customer-oriented and service-giving institutions. When the customers are satisfied with the centers they involve in, they will come again, that is why, the presentation of services, products and activities are important for the sport facilities like in the other service enterprises. In order to meet customer demands, the requirement for giving quality-service pushes the managers of sport facilities to make continual improvement efforts. Since customers are in expectation of the increasing quality, not giving quality-service will be resulted in a customer loss problem. Expectations and participation reasons for each customer who always goes to the sport facilities are different. Some customers for having a healthy life, some customers for reducing stress, some of them completely for losing weight participate in these programs. In today's society, the unlimited service is important, even though expectations can never end out, coming up with the new solutions in the shortest time will be an important factor in being chosen that enterprise by the customer (8).

Quality is determined by any person's performance, and related with this one. Considering the abilities of people working in the sport enterprises, it is inevitable to put quality-control techniques in this sector into practice. A customer decides whether the quality of given service is satisfying or not. Since a customer's satisfaction level rapidly changes, the sport enterprises need to develop a system focused on the customer satisfaction (7). Covering customers' expectations in the services given by the sport enterprises, presenting the service of quality and effectively by using the current developed sportive activities and sport tools away from errors must be aims for the management of sport enterprises (7). This study's aim was to determine the activities performed in the sport services by the municipalities among the local management units, to measure and evaluate the viewpoints of the public benefiting from these services.

\section{MATERIAL \& METHODS}

\section{Research Sampling and Group}

The research sampling consists of the individuals participated in the sport course branches such as condition, step, aerobics, fitness, as the members of 26 courses and art centers giving services depending on the Konya Metropolitan Municipality and Central District Municipalities.

The research group was totally made up of the 300 participants including 90 persons from the center of fine arts within the body of the Konya Meram District Municipality, 94 persons using the Ertuğrul Gazi Social Facility of the Konya Meram District Municipality and 115 persons from the Vocational Course Center of the Karatay Municipality depending on the Konya Karatay District Municipality. The relevant participants were determined from the individuals taking education in the branches of condition, step, aerobics, fitness in 
the course centers with the randomly sampling method.

\section{Data Collection Tool}

In our study, the HKDÖ (Scale for Service Quality Assessment) developed by Lam (16), and estimated in terms of Turkish validity and reliability by Gürbüz (14), was applied. The relevant form aims to measure the service quality in the health and vitality (sport-fitness) centers. The HKDÖ with 5 sub-dimensions involves 40 articles. These subdimensions; Workers (9 articles), Program (7 articles), Changing Rooms (5 articles), Facility (13 articles), Child Care (6 articles). Within this research, 4 of the 5 sub-dimensions were used. Since the department of child care was not often available in the course centers of the research, the Child Care sub-dimension was not preferred. The subdimension of workers investigates how the persons working in the centers communicate with the members, whether they have necessary information and skills in their fields or not, whether they are kind and patient. The program sub dimension also investigates the subjects such as the quality and content of the programs related with the sport activities, the efficiency of the programs. The subdimension of changing rooms asks whether there is a changing room, if available, how it is cleaned, generally maintained. The facility sub-dimension researches on the parking opportunities, the tools and equipments of facility, heating, lightening. The scale is Likert type, between 1 (less important) and 7 (very important) at the service dimension expected to be in degree, between 1 (weak) and 7 (great) at the service dimension perceived.
Also, the participants' personal information was obtained while collecting data with the HKDÖ. These are; gender, marital status, education level, monthly income, access time to facility, membership time for facility, usage frequency of facility.

\section{Data Analysis}

In evaluation of data and estimation of values, the SPSS 16.0 statistical package program was used. Data were summarised in giving averages and standard deviations. The One-Sample KolmogorovSmirnov test was done to determine whether data showed a normal distribution, and it was determined that data were indicators of a normal distribution. Since data represented a normal distribution, the Independent-Sample $\mathrm{T}$ test and the ANOVA test were used to determine differences between the independent variables. From the multiple comparison tests, the Tukey test indicated what the differences between the independent variables resulted from. In this study, the error level was regarded as 0.05 .

\section{RESULTS}

Looking at Table 1, when compared the perceived service quality of the persons participated in the research under the membership type, the points of service quality relating to the changing rooms from the persons being members as a family were meaningfully higher than the points of service quality relating to the changing rooms from the persons being members as an individual $(\mathrm{P}<0.05)$. However, any significant differences were not statistically determined in the other sub-dimensions $(\mathrm{P}>0.05)$.

Table 1. Comparisons of the expected and perceived service quality in the membership type among the participant members.

\begin{tabular}{|c|c|c|c|c|c|c|c|}
\hline & Variables & Membership type & $\mathrm{N}$ & Mean & SD & $\mathrm{t}$ & $\mathrm{P}$ \\
\hline \multirow{8}{*}{ Expected } & \multirow{2}{*}{ Staff } & Individual & 261 & 59.57 & 5.787 & \multirow{2}{*}{-1.225} & \multirow{2}{*}{0.221} \\
\hline & & Family & 37 & 60.78 & 4.571 & & \\
\hline & \multirow{2}{*}{ Program } & Individual & 261 & 45.65 & 5.178 & \multirow{2}{*}{-0.925} & \multirow{2}{*}{0.356} \\
\hline & & Family & 37 & 46.49 & 4.981 & & \\
\hline & \multirow{2}{*}{ Changing Rooms } & Individual & 261 & 32.17 & 4.710 & \multirow{2}{*}{-0.442} & \multirow{2}{*}{0.659} \\
\hline & & Family & 37 & 32.54 & 4.735 & & \\
\hline & \multirow{2}{*}{ Facility } & Individual & 261 & 82.53 & 10.625 & \multirow{2}{*}{-0.785} & \multirow{2}{*}{0.433} \\
\hline & & Family & 37 & 84.00 & 10.630 & & \\
\hline \multirow{8}{*}{ Perceived } & \multirow{2}{*}{ Staff } & Individual & 261 & 55.55 & 9.328 & \multirow{2}{*}{-0.511} & \multirow{2}{*}{0.610} \\
\hline & & Family & 37 & 56.41 & 11.174 & & \\
\hline & \multirow{2}{*}{ Program } & Individual & 261 & 43.93 & 8.947 & \multirow{2}{*}{-0.148} & \multirow{2}{*}{0.882} \\
\hline & & Family & 37 & 44.16 & 8.174 & & \\
\hline & \multirow{2}{*}{ Changing Rooms } & Individual & 261 & 28.51 & 6.689 & \multirow{2}{*}{-2.386} & \multirow{2}{*}{$0.018^{*}$} \\
\hline & & Family & 37 & 31.27 & 5.900 & & \\
\hline & \multirow{2}{*}{ Facility } & Individual & 261 & 75.90 & 12.143 & \multirow{2}{*}{-1.791} & \multirow{2}{*}{0.074} \\
\hline & & Family & 37 & 79.73 & 12.509 & & \\
\hline
\end{tabular}


Table 2. Comparisons of the expected and perceived service quality in the membership time among the participant members.

\begin{tabular}{|c|c|c|c|c|c|c|}
\hline & Variables & Membership Time & Mean & SD & $t$ & $\mathrm{P}$ \\
\hline \multirow[t]{8}{*}{ Expected } & \multirow[t]{2}{*}{ Staff } & Less than 1 year & 60.45 & 3.986 & \multirow[t]{2}{*}{3.367} & \multirow[t]{2}{*}{$0.001^{*}$} \\
\hline & & More than 1year & 58.11 & 8.020 & & \\
\hline & \multirow[t]{2}{*}{ Program } & Less than 1 year & 46.22 & 4.422 & \multirow[t]{2}{*}{2.344} & \multirow[t]{2}{*}{$0.020^{*}$} \\
\hline & & More than 1year & 44.72 & 6.394 & & \\
\hline & \multirow[t]{2}{*}{ Changing Rooms } & Less than 1 year & 32.59 & 4.299 & \multirow[t]{2}{*}{2.012} & \multirow[t]{2}{*}{$0.045^{*}$} \\
\hline & & More than 1year & 31.41 & 5.435 & & \\
\hline & \multirow[t]{2}{*}{ Facility } & Less than 1 year & 83.80 & 10.165 & \multirow[t]{2}{*}{2.633} & \multirow[t]{2}{*}{$0.009^{*}$} \\
\hline & & More than 1year & 80.35 & 11.242 & & \\
\hline \multirow[t]{8}{*}{ Perceived } & \multirow[t]{2}{*}{ Staff } & Less than 1 year & 56.29 & 9.131 & \multirow[t]{2}{*}{1.704} & \multirow[t]{2}{*}{0.089} \\
\hline & & More than 1year & 54.27 & 10.350 & & \\
\hline & \multirow[t]{2}{*}{ Program } & Less than 1 year & 44.44 & 9.726 & \multirow[t]{2}{*}{1.386} & \multirow[t]{2}{*}{0.167} \\
\hline & & More than 1year & 42.91 & 6.437 & & \\
\hline & \multirow[t]{2}{*}{ Changing Rooms } & Less than 1 year & 29.35 & 6.356 & \multirow[t]{2}{*}{1.862} & \multirow[t]{2}{*}{0.064} \\
\hline & & More than 1year & 27.74 & 7.168 & & \\
\hline & \multirow[t]{2}{*}{ Facility } & Less than 1 year & 77.29 & 11.793 & \multirow[t]{2}{*}{1.872} & \multirow[t]{2}{*}{0.063} \\
\hline & & More than 1year & 74.35 & 12.982 & & \\
\hline
\end{tabular}

Table 3. Comparisons of the expected and perceived service quality in the usage frequency of facilities among the participant members.

\begin{tabular}{lllcccc}
\hline \multicolumn{2}{c}{ Variables } & Sum of Squares & Mean Square & F & P \\
\hline \multirow{5}{*}{ Expected } & Staff & Usage Frequency of Facility & 64.271 & 32.135 & 1.004 & 0.368 \\
& Program & Usage Frequency of Facility & 118.642 & 59.321 & 2.253 & 0.107 \\
& Changing Rooms & Usage Frequency of Facility & 43.515 & 21.758 & 0.982 & 0.376 \\
& Facility & Usage Frequency of Facility & 994.956 & 497.478 & 4.516 & $0.012^{*}$ \\
& Staff & Usage Frequency of Facility & 920.467 & 460.233 & 5.178 & $0.006^{*}$ \\
& Program & Usage Frequency of Facility & 37.470 & 18.735 & 0.238 & 0.788 \\
& Changing Rooms & Usage Frequency of Facility & 149.026 & 74.513 & 1.692 & 0.186 \\
& Facility & Usage Frequency of Facility & 576.359 & 288.180 & 1.938 & 0.146 \\
\hline
\end{tabular}

Examining at Table 2, when compared the expected service quality of the persons participated in the research under the membership time, the service quality points relating to the staff, the program, the changing rooms and the facility among the persons who had membership time less than 1 year as a family were estimated to be meaningfully higher than the persons with the membership time more than 1 year $(P<0,05)$. However, any significant differences were not determined in the service quality points relating to the staff, the program, the changing rooms and the facility when compared the perceived service quality under the membership time $(\mathrm{P}>0.05)$.

Looking at Table 3, the participant members' expected and perceived service quality was compared in the usage frequency of facility, among the persons who used the facility 1-2 times in a week, 3-4 times in a week and 5-6 times in a week, a statistically significant difference was seen between the facility sub-dimension concerning the expected service quality and the staff sub-dimension concerning the perceived service quality $(\mathrm{P}<0,05)$. On the other hand, any statistically significant differences were not observed in the sub-dimensions of staff, program and changing rooms relating to the expected service quality $(\mathrm{P}>0.05)$. By comparing the members' perceived service quality in the usage frequency of facility, among the persons who used the facility 1-2 times in a week, 3-4 times in a week and 5-6 times in a week, any statistically significant differences were seen between the sub-dimensions of program, changing rooms and facility concerning the perceived service quality $(\mathrm{P}>0.05)$.

Examining at Table 4., in comparisons of the expected service quality concerning the members involved in the research under the usage frequency of facility, it was observed that the service quality points of the persons using the facility 1-2 times in a week were higher than the service quality points of the persons who used the facility 5-6 times in a week $(\mathrm{P}<0.05)$. Also, in comparisons of the perceived service quality in terms of the usage frequency of facility, it was seen that the service quality points of the persons who used the facility 1-2 times in a week were higher than the others $(\mathrm{P}<0.05)$. In other comparisons, any meaningful differences were not in question $(\mathrm{P}>0.05)$. 
When examined Table 5, while making comparisons of the expected service quality concerning the members participated in the research under the age groups, between all the subdimensons related with the expected service quality, a statistically significant difference was considered ( $>0.05)$. While comparing the perceived service quality in the age groups, among the persons aged less than 18 years-old, between 18-25 years, 26-35 years, 36-50 years, 51-65 years and over 65 years, it was determined that there was a significant difference between the staff sub-dimension related with the perceived service quality $(\mathrm{P}<0.05)$, there were not any significant differences between the other sub-dimensions $(\mathrm{P}>0.05)$.

Table 4. Multi-comparisons of the expected and perceived service quality in the usage frequency of facilities among the participant members.

\begin{tabular}{|c|c|c|c|c|c|c|}
\hline Variables & & (I) Usage Frequency of Facility & (J) Usage Frequency of Facility & Mean Difference (I-J) & Std. Error & $\mathrm{P}$ \\
\hline \multirow[t]{4}{*}{ Expected } & Facility & 1-2 times in a week & 3-4 times in a week & -1.424 & 1.376 & 0.556 \\
\hline & & & 5-6 times in a week & $-5.176^{*}$ & 1.739 & $0.009^{*}$ \\
\hline & & 3-4 times in a week & 1-2 times in a week & 1.424 & 1.376 & 0.556 \\
\hline & & & 5-6 times in a week & -3.752 & 1.634 & 0.058 \\
\hline \multirow[t]{4}{*}{ Perceived } & Staff & 1-2 times in a week & 3-4 times in a week & 1.724 & 1.233 & 0.343 \\
\hline & & & 5-6 times in a week & $5.013^{*}$ & 1.559 & $0.004^{*}$ \\
\hline & & 3-4 times in a week & 1-2 times in a week & -1.724 & 1.233 & 0.343 \\
\hline & & & 5-6 times in a week & 3.289 & 1.468 & 0.066 \\
\hline
\end{tabular}

Table 5. Comparisons of the expected and perceived service quality in the age groups among the participant members.

\begin{tabular}{|c|c|c|c|c|c|c|}
\hline \multicolumn{3}{|c|}{ Variables } & Sum of Square & Mean Square & $\mathrm{F}$ & $\mathrm{P}$ \\
\hline \multirow[t]{4}{*}{ Expected } & Staff & Age Groups & 128.910 & 32.228 & 1.007 & 0.404 \\
\hline & Program & Age Groups & 92.960 & 23.240 & 0.874 & 0.480 \\
\hline & Changing Rooms & Age Groups & 50.219 & 12.555 & 0.563 & 0.689 \\
\hline & Facility & Age Groups & 61.475 & 15.369 & 0.135 & 0.969 \\
\hline \multirow[t]{4}{*}{ Perceived } & Staff & Age Groups & 1165.881 & 291.470 & 3.288 & $0.012^{*}$ \\
\hline & Program & Age Groups & 186.250 & 46.563 & 0.592 & 0.669 \\
\hline & Changing Rooms & Age Groups & 303.674 & 75.918 & 1.733 & 0.143 \\
\hline & Facility & Age Groups & 382.858 & 95.715 & 0.637 & 0.637 \\
\hline
\end{tabular}

Table 6. Multi-Comparisons of the staff sub-dimenson related with the perceived service quality in the age groups among the participant members.

\begin{tabular}{|c|c|c|c|c|}
\hline (I) Age & (J) Age & Mean Difference (I-J) & Std. Error & $\mathrm{P}$ \\
\hline \multirow[t]{4}{*}{ Less than 18 years } & Between $18-25$ years & -8.184 & 2.957 & $0.047^{*}$ \\
\hline & Between 26-35 years & -9.846 & 2.821 & $0.005^{*}$ \\
\hline & Between $36-50$ years & -8.431 & 2.739 & $0.019^{*}$ \\
\hline & Between 51-65 years & -10.075 & 3.083 & $0.011^{*}$ \\
\hline \multirow[t]{4}{*}{ Between $18-25$ years } & Less than 18 years & 8.184 & 2.957 & $0.047^{*}$ \\
\hline & Between $26-35$ years & -1.662 & 1.750 & 0.877 \\
\hline & Between $36-50$ years & -0.247 & 1.615 & 1.000 \\
\hline & Between 51-65 years & -1.891 & 2.148 & 0.904 \\
\hline \multirow[t]{4}{*}{ Between 26-35 years } & Less than 18 years & 9.846 & 2.821 & $0.005^{*}$ \\
\hline & Between $18-25$ years & 1.662 & 1.750 & 0.877 \\
\hline & Between $36-50$ years & 1.415 & 1.349 & 0.832 \\
\hline & Between 51-65 years & -0.228 & 1.955 & 1.000 \\
\hline \multirow[t]{4}{*}{ Between $36-50$ years } & Less than 18 years & 8.431 & 2.739 & $0.019^{*}$ \\
\hline & Between $18-25$ years & 0.247 & 1.615 & 1.000 \\
\hline & Between 26-35 years & -1.415 & 1.349 & 0.832 \\
\hline & Between $51-65$ years & -1.644 & 1.835 & 0.898 \\
\hline
\end{tabular}

Looking at Table 6, when compared the staff sub-dimension related with the perceived service quality in the participant members' age groups, the service quality points concerning the members aged less than 18 years were estimated to lower than the points of the persons aged between 18-25 years, 2635 years, 36-50 years, 51-65 years and over 65 years $(\mathrm{P}<0.05)$. In the other comparisons, any significant differences were not observed in the service quality 
points relating to the staff in terms of the age groups $(\mathrm{P}>0.05)$.

Also, it was identified that there were no statistically significant differences in all the subdimensions related with the expected and perceived service quality while looking at the variables of access time, marital status, income and education level among the persons participated in the research.

\section{DISCUSSION}

In this research carried out in the sport centers depending on the Konya Meram and Karatay District Municipalities, the members were evaluated in accordance with the variables such as their satisfaction about the course centers (in terms of workers, programs, facilities and changing rooms of the course center), the membership type and time, the usage frequency of centers, the access time, the age, the marital status, the income level and the education level, and the results were interpreted with similar studies.

As a result of the comparisons of the expected and perceived service quality related with the members participated in the research in terms of the membership type, it was found that there were no statistically significant differences between the expected and perceived service quality points aimed at the persons being members individually or as a family within the sub-dimensions of staff, program and facility $(\mathrm{P}>0,05)$ (Table 1$)$. The service quality points relating to the changing rooms were statistically found to be higher in the persons being members as a family than the persons being members as an individual $(\mathrm{P}<0,05)$ (Table 1$)$.

In a research aimed at the sport enterprises by Akgül et al. (2), it was reported that especially the service issues relating to the changing rooms had more importance in the fitness centers for customers or members than the other sub-dimensions. Our study's findings also showed that in the individuals being members as a family, the family life provided necessary order, and these individuals gave more importance to hygienic conditions than the group being members individually.

As a result of the comparisons of the expected and perceived service quality in the relevant members in terms of the membership time, the service quality points relating to the staff, the program, the changing rooms and the facility among the persons who had a membership time less than 1 year were estimated to be higher than the persons who had a membership time more than 1 year $(\mathrm{P}<0.05)$. However, in the comparisons of the perceived service quality concerning to the members in terms of the membership time, there were not any significant differences in the service quality points relating to the staff, the program, the changing rooms and the facility between the persons having a membership time less than 1 year and the persons having a membership time more than 1 year $(\mathrm{P}>0.05)$.

Memiş \& Ekenci (17), suggest that the continuity of the service quality decreased in customers benefiting from the sport facilities for one year and over it in time. This situation requires that the sport enterprises especially give a separate importance to the promotion efforts for customers. Because customers expect that the enterprises renew themselves and tend to the service quality dimensions more carefully.

In accordance with Ceyhun's study (5), when the participants' usage time (year) for a facility within the sub-dimension of workers increased, the satisfaction level at the dimension of workers reduced. With the findings of the same research, at the sub-dimensions of physical characteristics of facility, program and additional service units (changing rooms), the satisfaction about the physical characteristics of facility, programs and additional service units reduced when the members' usage time (year) for the facility increased. The users' usage time for a facility (yearly) decreased in a direct proportion with the points given for the service quality. That is, the customers thought that the enterprises were not satisfying with the service quality in the period of their study.

The research results support our study findings. It can be said that there is an inverse proportion between the members' usage time for the facility and the satisfaction level. A lack of interest for enterprises in old members in comparison with new members can be an objective for having profitness at a maximum level by increasing the number of members in commercially active facilities. But this situation can be stated as a desire for presenting service to more people instead of a certain group by communicating with more members rather than profitness in municipality facilities which are the subject of our study.

When compared to the expected service quality associated with the members included in our study in terms of the usage frequency of facility, it was 
observed that there was no statistically significant difference in the sub-dimensions of staff, program and changing rooms relating to the expected service quality among the persons who used the facility 1-2 times in a week, 3-4 times in a week and 5-6 times in a week $(\mathrm{P}>0.05)$. Also, when compared to the members' perceived service quality in the usage frequency of facility, it was determined that there was no statistically significant difference in the subdimensions of program, changing rooms and facility relating to the perceived service quality among the persons who used the facility 1-2 times in a week, 34 times in a week and 5-6 times in a week $(P>0.05)$.

Among the persons who used the facility 1-2 times in a week, 3-4 times in a week and 5-6 times in a week, when the expected and perceived service quality was compared in the usage frequency of facility, a significant difference was found out between the sub-dimension of facility relating to the expected service quality and the sub-dimension of staff relating to the perceived service quality $(\mathrm{P}<0.05)$.

As a result of the multi-comparisons of the expected and perceived service quality associated with the participant members in the usage frequency of facility, the service quality points relating to the facility by the persons who used the facility 1-2 times in a week were estimated to be statistically higher than the service quality points relating to the facility by the persons who used the facility 5-6 times in a week $(\mathrm{P}<0.05)$. A significant difference was not found in the other comparisons $(\mathrm{P}>0.05)$.

In Tüfekçi's study (22), titled with the Evaluation of Expectations and Perceptions Relating to the Service Quality in the Customers of Fitness Centers and Yüzgenç's study (23), titled with the Service Quality Given in the Sport Services by the Local Managements of Ankara, depending on participation periods, a significant difference was not observed in terms of service expectations and perceptions. The differences between the relevant studies and our findings only are related with the ones between the sub-dimension of facility relating to the expected service quality and the subdimension of staff relating to the perceived service quality. In the sport facilities depending on the municipalities, the satisfaction perceptions of the members using 5-6 times in a week were lower than the ones using less. This situation can be stated as various facility intensities and seance differences, if the relevant facility is required for serving more than its capacity at the other dimensions such as infrastructure and staff, the members' satisfaction degree can be possibly less. Also, the service level which members want to have, may increase day by day, even though a certain program of training is seemed to be enough at starting process, it must be revised in accordance with a sportsman or member's condition in next months. Not re-newed programs may reduce the satisfaction level of the members who often use the facility.

In evaluation of the access time of the members to the facility, comparing the expected and perceived service quality in the scope of the access time to the facility, it was seen that a significant difference was not available in the sub-dimensions of different time $(\mathrm{P}>0.05)$.

Yüzgenç's study (23), shows that members were not affected from the access time to the Youth Centers. That is to say, even if the members' access time to the centers changed, in the HKDÖ (Scale for Service Quality Assessment) points any changes were not observed. This difference was in favour of the members whose access time was less than 15 min. That is, among the members who reached at the facility more easily, the service quality perception levels relating to the changing rooms were higher than the ones who reached at it later. Memiş \& Ekenci's study (17), supports this situation. This study explains that an easy access was the most important factor as a reason for preferring the sport centers.

When examined the sub-dimensions, the reason for the relevant difference can be explained as transportation problems of a city which in the studies were done. In most great cities, traffic problem is experienced and as we know, it negatively affects life conditions. Due to our city's geographical structure and transportation opportunities, transportation problems may not be experienced in the facilities of which persons are members.

As a result of the comparisons of the expected service quality associated with the participant members in the age groups, among all the subdimensions, there was not a significant difference in the expected service quality ( $P>0.05)$. By comparing the perceived service quality associated with the participant members from the age groups, there was a significant difference in the staff sub-dimension relating to the perceived service quality among the persons who were aged less than 18 years-old, between the ages 18-25, 26-35, 36-50, 51-65 and over 
$65(\mathrm{P}<0.05)$. In the multi-comparisons of the expected service quality of the members involved in the research in accordance with the age groups, the service quality points of the persons aged less than 18 , relating to the staff were lower than the persons aged between 18-25, 26-35, 36-50, 51-65 and over 65 $(\mathrm{P}<0.05)$. This significant difference in the subdimension of staff was not seen in the other dimensions.

In Tüfekçi's study (22), any significant difference was not found in the one-dimensional variance analysis applied in the age variables. That is, the service expectations were closer to each other at all age intervals. In Afthinos et al.'s study (1), similar results were observed. But for only one subdimension of our study, other findings comply with the relevant studies. At the sub-dimension of staff, the service quality perceived by the members aged less than 18 was lower than the other age groups, the reason is for that the staff may not reply to the expectations of the relevant age group. In a fitness group, the members aged less than 18 as a minority group, may not conform to other members and staff.

In terms of the marital status, when the service quality was examined, by comparing the expected and perceived service quality associated with the members involved in the research, it was determined that there were not any significant differences in the service quality points relating to all the sub-dimensions between the married and single persons $(\mathrm{P}>0.05)$.

In this regard, the studies different from our study are available. In accordance with Gençer et al.'s study (12), the married sport tourists' perceptions about the service quality relating to the skiing educators at the workers dimension were meaningfully positive than the single ones. The reason is for that the married sport tourists had more positive perceptions of service quality relating to the workers than the single ones, these individuals give more importance to the workers due to being individuals conscious and responsible. In Yüzgenç's research (23), the married members' perception levels about the workers, the program and the facility were higher than the perception levels of the single members. This situation is related that the married members are socially more relaxed and experienced, that they have less expectations rather than the single ones.

When the expected and perceived service quality was comparised in the members' income level, between all the sub-dimensions concerning the expected and perceived service quality any significant difference was not found $(\mathrm{P}>0.05)$.

Ardıç et al.'s research (3), titled with the Measurement of Service Quality (Citizen Satisfaction) in the Municipalities (An Application in the Tokat Municipality) supports our study findings as well, with this research any significant relation was not found between the perceived general service quality and income levels of citizens. Income levels do not affect the satisfaction level related with the service quality.

But in Ceyhun's study (5), the points from the members with the low income level were estimated to be higher, looking at the program sub-dimension considering a family's monthly income position on average. That is more, when income level increased, the satisfaction level decreased in the program subdimension. Boz's research (4), is in parallel with Ceyhun's research (5). According to Boz, when customers' income level increases, if necessary, managers seem to be open to discuss problems with them, thus when income level increases, communicating with workers becomes easier and more effective.

Furthermore, when people's income levels increase, their service expectations reach at high levels. Municipalities are required for making plans towards the general situation of public in their services, so this one can cause service unsatisfaction in terms of the individuals with high level of income.

When the participant members' expected and perceived service quality was compared in education levels, there were no significant differences in all the sub-dimensions related with the expected and perceived service quality among the persons who had an education level of primary and secondary school, high school and university $(\mathrm{P}>0.05)$.

In Yüzgenç's study (23), in accordance with the education level, the HKDÖ general points show that members did not have any effects of the education levels. That is, the members from the different education levels did not lead to any changes in the HKDÖ points. This result corresponds with the findings of our study.

On the other hand, according to Theodorakis et al.'s research (21), there were significant differences in accordance with the individuals' education levels, 
the customers having the lowest education level (primary and secondary school) were more satisfied with the facility dimension than the graduates of high school and university. The findings about the education level are related with the different expectations from the education groups. As a more difficult group, more educated individuals have high expectations from the services. This one can be explained that individuals have more information about fitness and more experiences in the sport services.

Boz (4), suggests that there was a good relation between the service presentation quality and the education level of trainers working in the facility $(\mathrm{P}<0.05)$. When the education level went up, the satisfaction level was significantly lowered. This situation indicates that customers having high level of education pay more attention to details and wait for more interest. And there are no relations between the education variable and the other variables.

In conclusion, in this study focused on the viewpoints of the persons who were members of the course centers depending on the Meram and Karatay District Municipalities in the Konya Province and participated in the sport activities of these centers about the service quality;

Within the opinions of the members involved in this research on the expected and perceived service quality, it can be said that membership type, membership time, usage frequency of facility and members' age variables are effective. Moreover, it will be appropriate for evaluating the satisfaction level, complaints and opinions of members at regular intervals in order to increase the service quality in the municipal sport centers having sport activities. Workers' education, capability, information level, capacity and teaching ability should not be ignored, this position is ultimately significant for communication with the members from each part and age group. And programs can be renewed and hygienic conditions in the changing rooms can be necessary to be given more importance in order to fulfill satisfaction of ones who have been using the facility for a long time, about the program and the changing room. In addition to our study, the next researches on expectations and satisfaction levels of the individuals benefiting from the sport services given by the municipalities in different residential areas will be useful for determining general problems related with this issue and finding common solution ways.

\section{REFERENCES}

1. Afthinos Y, Theodorakis ND, Nassis P. Customers' expectations of service in. Greek fitness centers'. Managing Service Quality Journal, 2005; 15(3): 245-258.

2. Akgül BM, Sarol H, Gürbüz B. The Determination of Service Quality in Sport Enterprises Giving Recreational Services. The Journal of Physical Education and Sport of Ankara Gazi University, 2009; 14(3): 33-39.

3. Ardıç K, Yüksel F, Çevik O. The measurement of service quality (citizen satisfaction) in municipalities (an application in the Tokat Municipality). The Journal of Modern Local Managements, 2004; 13(3) : 80.

4. Boz C. Total Quality Management Applications of Local Administrative Units in Sport Facilities (A Sample of the İstanbul Metropolitan Municipality). İstanbul, Marmara University Institute of Health Sciences, Department of Physical Education and Sport, Master Thesis. 2007: 134-135.

5. Ceyhun S. Service Quality in Sport Enterprises. Ankara, Gazi University Institute of Health Sciences, Department of Physical Education and Sport, Doctoral Dissertation. 2006: 132-140.

6. Çimen Z, Gürbüz B. Total Quality Management in Sport Services. Ankara: Alp Press, 2007: 20-22.

7. Demir EK. A Validity-Realiability Study of Quality Measurement in Enterprises Giving Recreational Sport Services. Ankara. Gazi University Institute of Health Sciences, Department of Physical Education and Sport, Master Thesis 2010: 39 .

8. Devecioğlu S, Gündoğdu C. Human resources planning in sports enterprises. The Journal of New World Sciences Academy, 2009; (1): 10-20.

9. Dönmez M. Municipality management. The Publication of Municipality Journal. 1999; (3): 3-4.

10. Ekenci G. Appropriateness of institutional cultures of sport clubs for total quality management in Turkey. The Journal of Physical Education and Sport Sciences of Gazi University, 2000;(5): 43-54.

11. Eryılmaz B.Public Management. (Volume 3). Ankara, Okutman Press. 2010:1-8,79-80.

12. Gencer RT, Demiray E. Türkiye'de toplam kalite yönetiminin futbolda uygulanabilirliği üzerine bir araştırma. Gazi Journal of Physical Education and Sports Sciences, 2003; 8(3): 25-38.

13. Gök Y, Sunay H. Comparisons of sport management in terms of public management in Turkey and France. The Spormetre Journal. 2010; (9): 7-16.

14. Gürbüz B. Turkish Validity-Realiability of Service Quality Assessment Scale. Middle East Technical University Institute of Social Sciences, Department of Physical Education and Sport, Master Thesis. 2003: 74-76.

15. Keleş R. Decentralization and Politics (Volume 4). İstanbul. Cem Press. 2000: 21-220.

16. Lam ETC. Service Quality Assessment Scale (SQAS): An Instrument for Evaluating Service Quality of Health-Fitness Clubs. Texas, University of Huston, The Department of Health and Human Performance, Unpublished Doctoral Dissertation.2000. 
17. Memiş UA, Ekenci G. Customer Satisfaction in sport centers (a sample of the Ankara Province). The Journal of Physical Education and Sport Sciences of Gazi University. 2007; 12(1): 33-48.

18. Nadaroğlu H. Theories/Economies/Applications of Local Administrative Bodies (Volume 7). İstanbul. Beta Press Publishing, 2001:7.

19. Öztürk A. A Local Management Model of the $21^{\text {st }}$ Century Turkey. İstanbul. Ümraniye Municipality Kültür Press. 1997: 34-36.

20. Seyidoğlu H. Encyclopedic Dictionary of Economic Terms. (Volume 3). Ankara Güzem Can Press. 1992: 438.

21. Theodorakis N, Alexandris K, Rodriguez P, Sarmento PJ. Measuring Customer Satisfaction in the Context of Health
Clubs in Portugal. International Sports Journal, 2004; 8(1): 4453.

22. Tüfekci Ö. Evaluation of Expectations and Perceptions About Service Quality in Customers of Fitness Centers. Balıkesir, Balıkesir University Institute of Social Sciences, The Department of Health and Human Performance, Master Thesis. 2010: 33-35.

23. Yüzgenç AA. Service Quality Given in Sport Enterprises by Local Managements (A Sample of the Ankara Province). Ankara, Gazi University Institute of Health Sciences, The Department of Health and Human Performance, Master Thesis. 2010:97-100-106. 